\title{
Effect of WBGT on physiological cost of operation for agricultural workers in southern Rajasthan
}

\author{
S. K. SINGH, A. K. MEHTA AND S. S. MEENA
}

\begin{abstract}
$\underline{\text { AbSTRACT }}$
Heat stress is a condition that is caused by worker over-exposure to the high temperature work environments often found in outdoor agriculture operations. Wet bulb globe temperature (WBGT) is a measure of heat stress especially when it is above 27 ${ }^{\circ} \mathrm{C}$. Considering the range of temperatures prevalent in the Rajasthan state of India during the months of May and June, agricultural operations during these months and the associated heat stress on the agricultural workers, this study was designed to ascertain the effect of WBGT on physiological cost of operation for agricultural workers. Southern Rajasthan was selected to conduct this study. Different WBGT of $28^{\circ} \mathrm{C}, 29^{\circ} \mathrm{C}, 30^{\circ} \mathrm{C}, 31^{\circ} \mathrm{C}$ and $32^{\circ} \mathrm{C}$ were selected for this study. The study conducted on twelve farm workers reveals that WBGT induces heat stress on the bodies of workers. The resting, working and delta heart rates and resting and working oxygen consumption rates of workers increased with increase of WBGT from $28^{\circ} \mathrm{C}$ to $32{ }^{\circ} \mathrm{C}$. The resting hear rate, working heart rate and $\Delta \mathrm{HR}$ was found increasing linearly with wet Bulb globe temperature with higher correlation. Resting and working OCR were also having increasing linear relationship with wet bulb globe temperature.
\end{abstract}

KEY WORDS : WBGT, Physiological cost, Operation, Agricultural workers

How to cite this Article : Singh, S.K., Mehta, A.K. and Meena, S.S. (2016). Effect of WBGT on physiological cost of operation for agricultural workers in southern Rajasthan. Engg. \& Tech. in India, 7 (2) : 78-83; DOI : 10.15740/HAS/ETI/7.2/ 78-83. 